магистрант группы ТБзм-19 кафедры «Экология и безопасность деятельности человека», ФГБОУ ВО «Ангарский государственный технический университет»,

e-mail:tarasovadasha99@gmail.com

Прусакова Александра Валерьевна,

к.м.н., дочент, дочент кафедры «Экология и безопасность деятельности человека», ФГБОУ ВО «Ангарский государственный технический университет», е-таil:

alprus@mail.ru

КОМПЕТЕНТНОСТНЫЕ ПРОБЛЕМЫ ОЦЕНКИ ПРОФЕССИОНАЛЬНЫХ РИСКОВ

Kiseleva D.A., Prusakova A.V.

\title{
COMPETENCE PROBLEMS OF PROFESSIONAL RISK ASSESSMENT
}

Аннотация. Дана характеристика оценки профессиональных рисков. Проведен анализ компетентности специалистов по охране труда для оценки профессиональных рисков.

Ключевые слова: оценка профессионального риска, специалист по охране труда, управление профессиональными рисками.

Annotation. The characteristics of the assessment of professional risks are given. The analysis of the competence of labor protection specialists for the assessment of occupational risks has been carried out. ment.

Keyword: professional risk assessment, labor protection specialist, professional risk manage-

Оценка профессиональных рисков представляет собой идентификацию опасностей (опасные и вредные производственные факторы, потенциально воздействующие на работников в процессе трудовой деятельности); определение вероятностей их наступления для каждой из выявленных опасностей; расчет значений показателей профессиональных рисков; определение, оценку риска их воздействия и расчет размеров возможных ущербов здоровью.

Целью оценки профессиональных рисков в организации является разработка наиболее эффективных мероприятий для улучшения условий труда на рабочем месте, так как она позволяет:

- получить обоснованные данные о существующем уровне риска жизни и здоровью работника в зависимости от условий труда;

- принять меры для снижения риска жизни и здоровью работника;

- информировать работника о существующем уровне профессиональных рисков на его рабочем месте и мерах, предпринимаемых работодателем, по снижению таких рисков;

- оценить эффективность применения средств индивидуальной защиты работника.

В результате осуществления оценки риска предприятие должно получить:
- информацию о состоянии условий труда, имеющихся опасностях на рабочих местах и рисках воздействия таких опасностей на работающих;

- перечни рисков, позволяющие выявить уязвимые места в обеспечении безопасности труда;

- информацию для принятия обоснованных решений по управлению рисками, а также позволяющую разработать и обеспечить меры по защите работающих от профессиональных рисков.

Цель данной статьи - рассмотрение проблем касающихся компетенций, предъявляемых к специалистам по охране труда при оценке профессиональных рисков.

Компетентностный подход к оценке профессиональных рисков является первоочередной задачей для выполнения мероприятий по снижению уровня высоких рисков или их полного устранения [1].

В сфере оценки профессиональных рисков существуют проблемы компетентности специалистов организаций, оценивающих данные риски на предприятии. Для эффективного управления рисками необходимы не только высококвалифицированные менеджеры, но и высококвалифицированные специалисты по охране труда.

Деятельность специалиста по охране труда должна быть направлена: 
- на профилактику несчастных случаев на производстве и профзаболеваний;

- на снижение уровня воздействия (устранение воздействия) на работников вредных и (или) опасных производственных факторов, уровней профессиональных рисков [2].

В соответствии с Приказом Министерства труда и социальной защиты Российской Федерации об утверждении профессионального стандарта «Специалист в области охраны труда» от 22 апреля 2021 года № 274H трудовая функция специалиста включает (п. 3.1.4 обобщенная трудовая функция):

- определение применимых в организации методов оценки вредных и (или) опасных производственных факторов, опасностей, профессиональных рисков на рабочих местах;

- выявление, анализ и оценка профессиональных рисков.

Согласно данной трудовой функции специалист в области охраны труда должен: выявлять и анализировать профессиональные риски в организации; проводить их оценку и принимать управленческие решения [2].

Профессиональный стандарт предусматривает следующие должности: младший специалист по охране труда, специалист по охране труда и главный (ведущий) специалист по охране труда. К данным должностям предъявляются следующие требования:

- к образованию и обучению:

- высшее образование - бакалавриат;

- высшее образование (непрофильное) - бакалавриат и дополнительное профессиональное образование - программы профессиональной переподготовки в области охраны труда;

- среднее профессиональное образование - программы подготовки специалистов среднего звена и дополнительное профессиональное образование в области охраны труда; работы;

- требования к опыту практической

- не менее трех лет в области охраны труда при наличии среднего профессионального образования для специалиста по охране труда;

- для занятия должности главный (ведущий) специалист по охране труда - не менее трех лет в области охраны труда при наличии высшего образования или не менее четырех лет в области охраны труда при нали- чии среднего профессионального образования;

- особые условия допуска к работе: обучение охране труда и проверка знаний требований охраны труда не реже одного раза в три года [2].

Специалист согласно данной трудовой функции должен уметь: применять методы оценки вредных и (или) опасных производственных факторов, опасностей, профессиональных рисков на рабочих местах; координировать проведение производственного контроля условий труда, специальной оценки условий труда, анализировать результаты; обосновывать приоритетность мероприятий по улучшению условий и охраны труда с точки зрения их эффективности; разрабатывать меры управления рисками на основе анализа принимаемых мер и возможности дальнейшего снижения уровней профессиональных рисков и другие.

При идентификации опасностей на рабочих местах в организации, представляющих угрозу жизни и здоровью работников, и составление их перечня осуществляются работодателем с привлечением службы (специалиста) охраны труда.

Этап оценки уровней профессиональных рисков проводиться с учетом:

- риска опасностей на предприятии;

- ущерба здоровью и жизни работника.

Методы оценки уровня профессиональных рисков определяются работодателем с учетом характера деятельности и сложности выполняемых операций. На практике применяются следующие виды методов:

- качественные (предполагают определение последствий, вероятности и уровня риска с помощью определенной шкалы);

- количественные (предусматривают оценку влияния последствий и вероятности их наступления);

- смешанные.

Допускается использование различных методов оценки уровня профессиональных рисков для разных процессов и операций.

Оценка рисков выполняется с применением прямых (используется статистическая информация по выбранным показателям риска или непосредственно показатели ущерба и вероятности их наступления) и косвенных (используются показатели, характеризующие отклонение существующих (контролируемых) условий (параметров) от норм и имеющие причинно-следственную 
связь с рисками) методов.

Если перед специалистами служб руководством будут поставлены задачи оценки, анализа рисков и управления ими, то специалист в области охраны труда должен знать методы и порядок оценки опасностей и профессиональных рисков работников, но в настоящее время отсутствует единый концептуальный подход и единая утвержденная практико-ориентированная методика [3]. Предлагаемый проект приказа «Об утверждении Рекомендаций по выбору метода оценки уровня профессионального риска и по снижению уровня такого риска» [4] предлагает работодателю самому выбирать методы оценки уровня профессиональных рисков, применяемых в Российской Федерации и зарубежной практике, а также разработать собственный метод оценки уровня профессиональных рисков, исходя из специфики своей деятельности.

Современные методы представлены качественными и количественными методами, при этом отсутствует единая общепринятая количественная оценка уровня профессионального риска в организации на основе одночисловой характеристики. Отсутствует методика ранжирования организаций по уровню профессионального риска на основе единого показателя, включающим все профессиональные риски работников в организации.

Вопрос оценки профессиональных рисков в профессиональном стандарте «Специалист в области охраны труда» также предусмотрен в трудовой функции: - 3.2 «Планирование, разработка и совершенствование системы управления охраной труда и оценки профессиональных рисков». При выполнении данной трудовой функции профессиональный стандарт предусматривает следующие должности: руководитель службы охраны труда, начальник отдела охраны труда и начальник управления охраной труда. При выполнении работ по выявлению, оценке и разработке мероприятий, направленных на снижение или устранение профессиональных рисков необходимы определенные требования к образованию, обучению и опыту практической работы специалиста по охране труда. К ним относятся:

- требования к образованию:

- высшее образование - магистратура, специалитет;
- высшее образование (непрофильное) - магистратура, специалитет и дополнительное профессиональное образование программы профессиональной переподготовки в области охраны труда;

- требования к опыту практической работы специалиста по охране труда - не менее пяти лет в области охраны труда;

- требования к обучению: обучение охране труда и проверка знаний требований охраны труда не реже одного раза в три года [2].

Специалист должен уметь:

- применять государственные нормативные требования охраны труда, межгосударственные, национальные и международные стандарты в сфере безопасности и охраны труда с целью обеспечения выполнения отдельных процедур системы управления охраной труда;

- анализировать лучшие практики построения системы управления охраной труда и оценивать возможности использования этого опыта;

- анализировать состояние производственного травматизма и профессиональных заболеваний;

- анализировать вероятность возникновения рисков на этапах производственной деятельности организации, ввода нового оборудования и технологических процессов;

- обеспечивать проведение профилактической работы по предупреждению производственного травматизма, профессиональных заболеваний и заболеваний, обусловленных производственными факторами, а также работы по улучшению условий труда;

- проводить расчеты необходимого финансового обеспечения для реализации мероприятий по улучшению условий и охраны труда и снижению уровней профессиональных рисков и другие.

Выявлением, анализом и оценкой профессиональных рисков на предприятии должен заниматься как руководитель, так и специалист по охране труда непосредственно. Поэтому возникает необходимость в грамотных высококвалифицированных специалистах в области охраны труда.

Квалификация специалиста по охране труда напрямую влияет на эффективность системы управления охраной труда на предприятии. 
Таблица 1 Уровни компетентности специалистов по охране труда для оценки профессиональных рисков с учетом профессиональных образовательных программ и курсов Уровни компетентности специалистов по охране труда (на основе перечня профессиональных образовательных программ и курсов)

Высшее образование по направлению «Техносферная безопасность» (магистратура), «Сертификат специалиста по ОТ» и опыт в должности специалиста по ОТ не менее года

Высшее образование по направлению «Техносферная безопасность» (магистратура)

Высшее образование по направлению «Техносферная безопасность» (бакалавриат), «Сертификат специалиста по ОТ» и опыт в должности специалиста по ОТ не менее 3 лет

Высшее образование по направлению «Техносферная безопасность» (бакалавриат)

Высшее техническое образование, дополнительное профессиональное образование (профессиональная переподготовка) и «Сертификат специалиста по охране труда»

Высшее техническое образование и дополнительное профессиональное образование (профессиональная переподготовка)

Высшее гуманитарное образование, дополнительное профессиональное образование (профессиональная переподготовка) и «Сертификат специалиста по охране труда»

Высшее гуманитарное образование и дополнительное профессиональное образование (профессиональная переподготовка)

Наличие соответствующих компетенций в ФГОС ВО $(3++)[5,6,7,8]$

Универсальные компетенции: УК-1 - УК-6

Общепрофессиональные функции:

ОПК-1 - ОПК-5

Профессиональные компетенции определяются на основе профессиональных стандартов

Универсальные компетенции:

УК-1 - УК-6

Общепрофессиональные компетенции: ОПК-1 - ОПК-5

Профессиональные компетенции опреде-

ляются на основе профессиональных стандартов

Универсальные компетенции:

УК-1 - УК-11

Общепрофессиональные функции:

ОПК-1 -ОПК-5

Профессиональные компетенции определяются на основе профессиональных стандартов

Универсальные компетенции:

УК-1 - УК-11

Общепрофессиональные функции:

ОПК-1 - ОПК-5. Профессиональные компетенции определяются на основе профессиональных стандартов

Универсальные компетенции:

УК-1 - УК-10

Общепрофессиональные функции:

ОПК-1 - ОПК-5

Профессиональные компетенции определяются на основе профессиональных стандартов

Универсальные компетенции:

УК-1 - УК-10

Общепрофессиональные функции:

ОПК-1 - ОПК-5

Профессиональные компетенции определяются на основе профессиональных стандартов

Универсальные компетенции: УК-1 - УК11

Общепрофессиональные функции:

ОПК-1 - ОПК-9

Профессиональные компетенции определяются на основе профессиональных стандартов

Универсальные компетенции: УК-1 - УК11

Общепрофессиональные функции:

ОПК-1 - ОПК-9

Профессиональные компетенции определяются на основе профессиональных стандартов
Способность оценивать профессиональные риски [3]

\section{Возможно}

Возможно.

Вызовет затруднения практического характера

Возможно.

Вызовет затруднения методологического характера

\section{Возможно.}

Вызовет затруднения методологического и практического характера

Невозможно

Невозможно

Невозможно

\begin{tabular}{l|l|} 
& \\
\hline & Невозможно \\
\hline Незожно & \\
\hline Невозможно & \\
\hline & \\
\hline
\end{tabular}

Примечание: ФГОС ВО - Федеральный государственный образовательный стандарт высшего образования 
Предполагаемые уровни компетентности, которые позволят выпускникам вузов по направлению подготовки «Техносферная безопасность» справиться с этой задачей, с учетом данных [3], представленных в таблице 1. Федеральные государственные образовательные стандарты высшего образования бакалавриат, и магистратура содержат универсальные и общепрофессиональные компетенции, профессиональные компетенции $[5,6,7,8]$ определяются организацией самостоятельно на основе профессиональных стандартов.
Стоит отметить, что без высшего образования по направлению «Техносферная безопасность», оценивать профессиональные риски, в большинстве случаев, не представляется возможным [3]. Таким образом, для оценки профессионального риска на предприятии необходима соответствующая компетентность, которая достигается при обучении в вузе по направлению подготовки «Техносферная безопасность». При этом для ряда уровней компетентностей необходим и практический опыт работы в организации.

\section{СПИСОК ЛИТЕРАТУРЫ}

1. Оценка рисков на рабочем месте: практическое пособие / [М. Муртонен].

2. Приказ Министерства труда и социальной защиты Российской Федерации от22 апреля 2021 года № 274н «Об утверждении профессионального стандарта «Специалист в области охраны труда». [Электронный реcypc] URL: https://base.garant.ru/70731928/ (дата обращения: 20.09.2021).

3. Определение индивидуального профессионального риска: учеб. пособие / [В. С. Сердюк и др.]; Минобрнауки России, ОмГТУ. - Омск: Изд-во ОмГТУ, 2016.

4. Проект Приказа Минтруда России «Об утверждении Рекомендаций по выбору метода оценки уровня профессионального риска и по снижению уровня такого риска» [Электронный pecypc] URL:http://www. consultant.ru/law/hotdocs/69842.html/ (дата обращения: 20.09.2021).

5. Приказ Министерства науки и высшего образования Российской Федерации от 25 мая 2020 г. № 680 «Об утверждении Федеральный государственный образовательный стандарт высшего образования уровень высшего образования - бакалавриат направление подготовки 20.03.01 Техносферная безопасность» [Электронный ресурc] URL: http://fgosvo.ru/uploadfiles/FGOS VO 3++/ (дата обращения: 04.10.2021).
6. Приказ Министерства науки и высшего образования Российской Федерации от 25 мая 2020 г. №678 «Об утверждении Федеральный государственный образовательный стандарт высшего образования уровень высшего образования - магистратура направление подготовки 20.04.01 Техносферная безопасность» [Электронный pecypc] URL: http://fgosvo.ru/uploadfiles/FGOSVO3++/Mag (дата обращения: 04.10.2021).

7. Приказ Министерства науки и высшего образования РФ от 7 августа 2020 г. №890 «Об утверждении Федеральный государственный образовательный стандарт высшего образования уровень высшего образования - бакалавриат по направлению подготовки 03.03.01 Прикладные математика и физика» [Электронный pecypc] URL: http://fgosvo.ru/uploadfiles/FGOSVO 3++ (дата обращения: 09.10.2021).

8. Приказ Министерства науки и высшего образования РФ от 13 августа 2020 г. № 1011 «Об утверждении федерального государственного образовательного стандарта высшего образования - бакалавриат по направлению подготовки 40.03.01 Юриспруденция» [Электронный ресурc] URL: http:// fgosvo.ru/uploadfiles/FGOSVO 3++ (дата обращения: 09.10.2021). 